\title{
Impacts of nitrogen deposition on vascular plants in Britain: an analysis of two national observation networks
}

\author{
P. A. Henrys ${ }^{1}$, C. J. Stevens ${ }^{2,3}$, S. M. Smart ${ }^{1}$, L. C. Maskell ${ }^{1}$, K. J. Walker ${ }^{4}$, C. D. Preston $^{5}$, A. Crowe ${ }^{1}$, E. C. Rowe , $^{6}$ \\ D. J. Gowing ${ }^{2}$, and B. A. Emmett ${ }^{6}$ \\ ${ }^{1}$ Centre for Ecology and Hydrology, Lancaster Environment Centre, Bailrigg, Lancaster, LA1 4AP, UK \\ ${ }^{2}$ Department of Environment, Earth and Ecosystems, The Open University, Walton Hall, Milton Keynes, MK7 6AA, UK \\ ${ }^{3}$ Lancaster Environment Centre, Lancaster University, Lancaster, LA1 4YQ, UK \\ ${ }^{4}$ Botanical Society of the British Isles (BSBI), c/o 97 Dragon Parade, Harrogate, North Yorkshire, HG1 5DG, UK \\ ${ }^{5}$ Centre for Ecology and Hydrology, Maclean Building, Benson Lane, Crowmarsh Gifford, Wallingford, \\ Oxfordshire, OX10 8BB, UK \\ ${ }^{6}$ Centre for Ecology and Hydrology, Environment Centre Wales, Deiniol Road, Bangor, Gwynedd, LL57 2UW, UK
}

Received: 1 July 2011 - Published in Biogeosciences Discuss.: 25 July 2011

Revised: 7 November 2011 - Accepted: 9 November 2011 - Published: 1 December 2011

\begin{abstract}
Large areas of Great Britain currently have nitrogen $(\mathrm{N})$ deposition at rates which exceed the thresholds above which there is risk of damage to sensitive components of the ecosystem (critical loads). Previous studies have focussed primarily on the relationship of species richness to nitrogen, whereas here we look at individual species. We used data from two national observation networks over Great Britain to examine the response of individual vascular plant species to $\mathrm{N}$ in acid grasslands, calcareous grasslands and heathlands. Presence absence records of individual species, along with mean Ellenberg $\mathrm{N}$ scores, within $10 \mathrm{~km}$ hectads were modelled against $\mathrm{N}$ deposition whilst at the same time controlling for the effects of climate, land use and sulphur deposition using generalised additive models. Ellenberg $\mathrm{N}$ showed a significant increase with increasing $\mathrm{N}$ deposition in almost all habitats across both surveys indicating increased fertility. Many individual species showed strong relationships with $\mathrm{N}$ deposition and clear negative trends in species prevalence to increasing nitrogen were found in all habitats. A number of these species were either habitat dominants or possessed traits known to be influential in controlling ecosystem function. Many community dominants showing significant negative relationships with $\mathrm{N}$ deposition highlight a potentially significant loss of function. Some species that
\end{abstract}

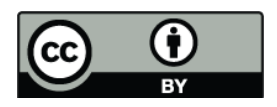

Correspondence to: P. A. Henrys (pehn@ceh.ac.uk) showed negative relationships to $\mathrm{N}$ showed signs of decline at low levels, far below the current critical load levels. Some species also showed continuous changes as $\mathrm{N}$ deposition levels rose above the current critical load values. This work contributes to the growing evidence base suggesting species level impacts at low $\mathrm{N}$ deposition values.

\section{Introduction}

Atmospheric nitrogen $(\mathrm{N})$ deposition poses a serious threat to sensitive semi-natural habitats in Great Britain (Hall et al., 2006a; RoTAP, 2011). Estimated levels of nitrogen (N) deposition across Great Britain and Northern Ireland are shown in Fig. 1. Large areas of the country exceed the critical loads for nutrient $\mathrm{N}$ and critical levels for ammonia, and are predicted to continue to do so in 2020 despite reductions in emissions of reactive $\mathrm{N}$ gases (Hall et al., 2006b). The critical load is defined as the level below which significant harmful effects on specified sensitive elements of the environment do not occur (Nilsson and Grennfelt, 1988). Therefore, by definition, as $\mathrm{N}$ levels surpass the critical load values there is possibility of a significant harmful effect on the environment. There is a growing body of evidence from both experiments and surveillance studies that suggest that increases in nitrogen have a negative effect on species richness and composition (e.g. Mountford et al., 1993; Wilson et al., 1995; Stevens

Published by Copernicus Publications on behalf of the European Geosciences Union. 
et al., 2004, 2010; Maskell et al., 2010; Dupré et al., 2010; Smart et al., 2004; Van den Berg et al., 2011).

A negative relationship between species richness and $\mathrm{N}$ leads us to hypothesise that some individual vascular plant species show a decline in frequency of occurrence with increased $\mathrm{N}$ and are perhaps not found at all in some areas due to high $\mathrm{N}$ deposition levels. However, as some species lose out, decline and potentially become eliminated from the ecosystem, with increased levels of $\mathrm{N}$, some species may flourish. Changes in mean indicator scores based on summarising changes across taxa can reveal strong signals of pollutant impacts. However, plant species respond individualistically so that assessment at an individual species level is required to understand how assemblage-level changes comprise different magnitudes and directions of change among the species present. Expressing habitat change at the species level also allows identification of potential indicators of air pollution and aids interpretation of critical load exceedance scenarios.

There have previously been a number of geographically large-scale studies attempting to determine the impact of total inorganic $\mathrm{N}$ deposition on vegetation in Great Britain. For example, Stevens et al. (2004) used a large scale spatial survey of acid grasslands to demonstrate declines in species richness, when high $\mathrm{N}$ deposition was compared with areas of low N deposition. In the RoTAP report (RoTAP, 2011) results of eleven surveys conducted in Great Britain and Northern Ireland are compared. Species richness declined with increasing $\mathrm{N}$ deposition in seven of the eleven surveys. Further to this, species richness of vascular plants has been found to decrease in response to $\mathrm{N}$ deposition in a number of experimental studies (e.g. Bobbink et al., 1998; Clark and Tilman, 2008; Mountford et al., 1993).

The Countryside Survey has also been used to study the impact of $\mathrm{N}$ deposition on semi-natural vegetation communities. Maskell et al. (2010) used data from the 1998 survey to show declines in species richness in both acid grassland and heathland along the gradient of $\mathrm{N}$ deposition covering Great Britain. Trait data was used to propose mechanisms for species loss. These appeared to vary by habitat type; in acid grassland and heathland acidification appeared to be the driving process rather than eutrophication (Maskell et al., 2010). In addition to this, large-scale analyses of UK and European data have also detected parallel signals of eutrophication (Dupré et al., 2010; Smart et al., 2004; RoTAP, 2011). As $\mathrm{N}$ deposition increases, plant species and traits associated with higher fertility have become more abundant and stresstolerant species have declined.

In some studies covering a range of habitats across Europe, Ellenberg values (Ellenberg et al., 1991; Hill et al., 1999) have been used as indicators of $\mathrm{N}$ deposition effects (Diekmann and Falkengren-Grerup, 2002; Jones et al., 2004). Ellenberg values describe the realised niche of a plant in relation to its tolerance of certain environmental conditions on a scale of one to nine. The most relevant to $\mathrm{N}$ deposition is the

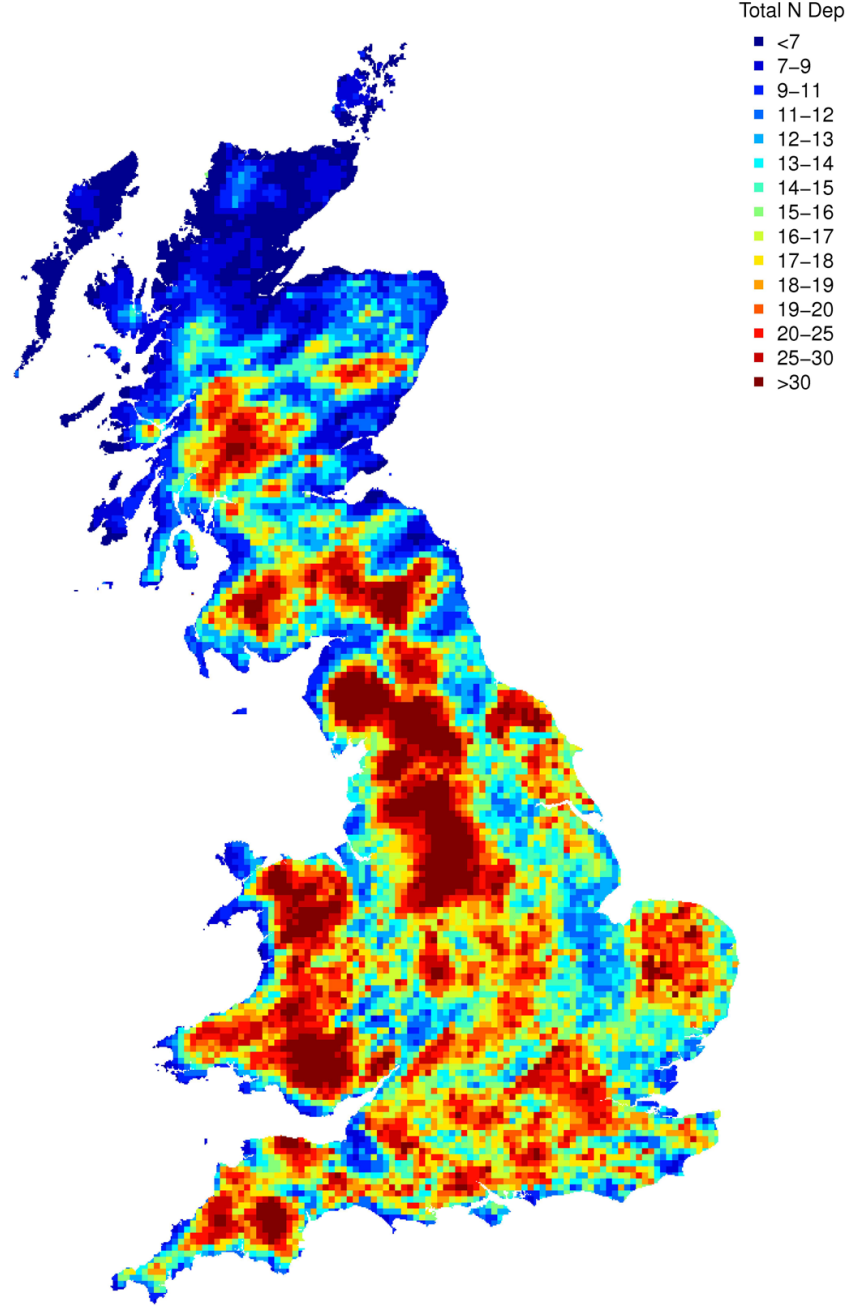

Fig. 1. Total inorganic $\mathrm{N}$ deposition $\left(\mathrm{kg} \mathrm{Nha}^{-1} \mathrm{yr}^{-1}\right)$ to heathland and rough grazing land in Great Britain. CBED deposition data for 1996-1998.

$\mathrm{N}$ score (nitrogen or nutrients). The Ellenberg N score indicates overall fertility or productivity (Hill and Carey, 1997).

However, none of these previous studies have focussed on relationships between individual species and $\mathrm{N}$, whilst at the same time accounting for other confounding factors such as climate. As the majority of air pollution policy is focussed on setting appropriate emissions ceilings and the consideration of critical load exceedance, evidence from analysing individual species responses to nitrogen needs to be considered so that critical loads are set at levels to protect the risk of species loss.

The main aim of this paper is to analyse vegetation surveillance datasets on a national scale, in terms of individual species responses and Ellenberg $\mathrm{N}$ scores, and collate evidence of possible $\mathrm{N}$ deposition impacts/relationships. This adds the growing evidence base and provokes thought on potential implications for current conservation commitments and biodiversity targets. These include the aim to maintain or 
improve the status of wild flora and fauna and their ecosystems and habitats in response to the Convention for Biological Diversity (CBD) Articles 8 and 9.

\section{Methods}

\subsection{Data}

Data were taken from two national vegetation datasets to look at relationships with $\mathrm{N}$ deposition for three semi-natural habitats: calcareous grassland; acid grassland; and heathland. The distributions of these three habitats over Great Britain are shown in Fig. 8. The databases used were: The Vascular Plant Database, which recorded the presence of all vascular plant species growing within $10 \mathrm{~km}^{2}$ hectads in the wild between 1987 and 1999 (Preston et al., 2002); and The Botanical Society of the British Isles (BSBI) Local Change Survey data which records all vascular plant species growing in the wild in $8112 \times 2 \mathrm{~km}$ tetrads located within a regular grid of $10 \mathrm{~km}^{2}$ hectads across Great Britain. The BSBI survey was conducted in both 1987-1988 and 2003-2004 (Braithwaite et al., 2006), but for this analysis only data from 2003-2004 was used. For the purposes of this assessment, any recorded subspecies were aggregated to the species level, with hybrids and alien species excluded, and pooled over time as the subsequent analysis uses only the spatial distribution of the data to inform the model.

Vascular plants were individually assigned to each of the target habitat types using published preference data on habitat affinity and altitudinal ranges (Hill et al., 2004). Only those species selected using the criteria above were subsequently used to generate summary variables. Thus generalist species and those restricted to other non-target habitats were excluded from the calculation of mean Ellenberg $\mathrm{N}$ values for each recording unit (i.e. tetrad or hectad).

Hectads $(10 \times 10 \mathrm{~km}$ squares $)$ and Tetrads $(2 \times 2 \mathrm{~km}$ square) were processed to determine upland and lowland strata and to locate focal Broad Habitats. Broad Habitat occurrence was derived from the Land Cover Map $200025 \mathrm{~m}$ raster coverage. The upland mask is composed of the upland delineation for England based on English Natural Areas, a Welsh upland mask provided by Countryside Council for Wales (CCW), and the combined upland and montane masks from Scottish Natural Heritage (SNH).

To understand fully the potential effects of $\mathrm{N}$ on vascular plants we investigated relationships between atmospheric $\mathrm{N}$ deposition and: individual species' responses (presence/absence in each recording unit based on current distribution); and Ellenberg N scores (Hill et al., 1999, 2007). This allowed us to identify species that are especially vulnerable to $\mathrm{N}$ deposition and those which are not found in areas of high deposition, whilst Ellenberg $\mathrm{N}$ scores allow us to assess the extent to which these different species patterns reflected prior knowledge of their association with different levels of fertility. Thus we calculated average Ellenberg N scores based on the presence of species within each habitat. $\mathrm{N}$ scores are on a scale of one to nine, where one represents the most infertile habitats and nine represents fertile habitats.

\subsection{Driver variables}

Ecological drivers known to affect species occurrence were included in the model so that the effects could be partialled out before looking into the relationship with total inorganic $\mathrm{N}$ deposition. Additional variables included were: intensity of land-use in each grid square; minimum January temperature; maximum July temperature; total annual rainfall; and change in sulphur deposition. Total annual rainfall was preferred to summer or winter rainfall due to the high correlation between the seasons $(>0.8)$ allowing the inclusion of only one term. For completeness, total annual rainfall was therefore favoured. Intensity of land use was measured as the proportion of arable plus improved grassland in the grid square as calculated from Land Cover Map 2000. Climate data was based on long term averages from the Met Office covering the period from 1980 to 2005 . This long term average provided good representation of the spatial variability in temperature, which was needed to capture the spatial differences in species occupancy we modelled. Sulphur (S) deposition was the difference in model estimates for 1971 and 2005 as based on the FRAME model (Fine Resolution Ammonia Exchange) (Fournier et al., 2000). For N deposition we used estimates at the $5 \mathrm{~km}^{2}$ scale provided by CEH Edinburgh (NEGTAP, 2001; Smith et al., 2000), calculated as the mean of the estimates for 1996, 1997 and 1998 from the CBED model for deposition to moorland. We may perhaps expect plant response to be a function of cumulative $\mathrm{N}$ deposition, however, data on this was not available, so current $\mathrm{N}$ deposition was used as a proxy for cumulative deposition. If cumulative data were based on back-casting from current deposition patterns (as in Dupré et al., 2010), we would expect to see very similar results. Whenever the resolution of the botanical records was greater than that of the driver variable data, the driver data were averaged over the size of the botanical recording unit.

\subsection{Modelling of response variables}

We used a generalised additive model (GAM) (Hastie and Tibshirani, 1990) based approach to model both species presence/absence and Ellenberg $\mathrm{N}$ scores. This allowed the effects of other covariates of interest to be modelled and accounted for before looking at the relationship between the response variable and $\mathrm{N}$. The flexible, non-linear, smooth terms used in the GAM framework allow for the possibility that a species may be unaffected beneath a certain level of $\mathrm{N}$ but showing signs of change beyond this threshold, thus conforming to the critical loads definition. 
Any spatial structure in the model residuals was accounted for in the GAM by including an additional two-dimensional smooth term, i.e. a planar surface, in the model. This term is defined as an interaction between the two coordinate axes. Therefore any spatial dependence between hectads, missing spatial covariates or spatially structured recording effort is accounted for as much as is possible. This, rather broad scale way of handling residual spatial structure was assessed by repeating a subset of models in a Bayesian framework allowing for a complex, localised, fine scale dependence structure to be specified. Results from such analyses confirmed that the broader scale dependence method of the GAMs performed equally as well. Furthermore, for the BSBI tetrad data a random effect term for hectad was also included to account for differing levels of variability to data from within the same hectad to data from differing hectads.

Finally, to maintain an element of consistency across the analyses, all models were started with the same set of terms and driver variables, which were included in the model in the same order.

\subsection{Model inference}

For both the hectad and tetrad models, regression parameters for any fixed linear terms and parameters for each of the smooth terms were estimated, together with standard errors, by either approximating the true likelihood or using quasi likelihood methods. Having fitted the model with all terms, individual terms were selected based on F-tests, the AIC score (Akaike, 1969) and the generalised cross validation score. Non significant terms were only removed if the AIC and GCV scores improved upon their removal. The covariate corresponding to $\mathrm{N}$ was always included in the model whether it was significant or not, as it was this relationship that ultimately we were interested in. The final model was checked by examining plots of residuals and quantilequantile plots of the observed and predicted values.

To formally assess the impact of $\mathrm{N}$, the p-value from the Ftest associated with the $\mathrm{N}$ covariate was returned along with a graphical plot of the estimated smooth term in the GAM for $\mathrm{N}$ deposition. Both the p-value and the plots together provide a full assessment of the modelled relationship, including significance, direction and change points, that $\mathrm{N}$ has in relation to the vegetation response variable.

Because of the complex modelling framework and the number of driver variables used in building the model, data sets with a small number of observations could not be analysed and were therefore removed. Also species with less than $10 \%$ and greater than $90 \%$ of presences in the data set were also removed as convergence in the model was difficult to achieve.
Table 1. The number of sampling units (hectads or tetrads) across Great Britain containing each of the three studied habitats from each of the two surveys.

\begin{tabular}{llrr}
\hline & Habitat & Lowland & Upland \\
\hline Vascular Plant & Acid grassland & 1143 & 1203 \\
Database & Calcareous grassland & 1546 & 662 \\
& Heathland & 855 & 1284 \\
\hline BSBI Local Change & Acid grasslands & 164 & 158 \\
survey data & Calcareous grasslands & 377 & 209 \\
& Heathland & 43 & 231 \\
\hline
\end{tabular}

\section{Results}

Results are presented separately for the analysis of the individual species' presence/absence and the calculated Ellenberg N score. Furthermore, each of the three habitats: calcareous grassland, acid grassland and heathland are listed individually for the species response analysis. The number of hectads within each of the three habitats for the two recording schemes is shown in Table 1. Histograms showing the ranges of $\mathrm{N}$ deposition covered within each habitat for which data were analysed are given in Appendix A.

It is important to note that the low sample sizes for analysis are not solely because of too few records in either recording scheme. It is the combination of sampling units coinciding with grid cells with identifiable and hence larger areas of the focal habitat, i.e. the presence records for species in cells where Land Cover Map did not pick up the habitat of interest were not included.

\subsection{Individual species response}

Removing the very rare and very common species from the analysis (those with an overall presence of less than $10 \%$ and greater than $90 \%$, respectively) the presence/absence of the remaining species occurring in the sampling units according to Table 1, was modelled as outlined above. P-values obtained from testing the null hypothesis of no association between presence/absence and $\mathrm{N}$ deposition, having accounted for other driver variables, are given in Appendix B for all species analysed. For species where a significant association with $\mathrm{N}$ deposition was found, the relationships are plotted as probability of presence against increasing total inorganic $\mathrm{N}$ deposition $\left(\mathrm{kg} \mathrm{Nha}^{-1} \mathrm{yr}^{-1}\right)$. The critical load for each habitat, as defined by the range midpoint of the published values by Bobbink and Hettelingh (2011), is also included in these plots. 


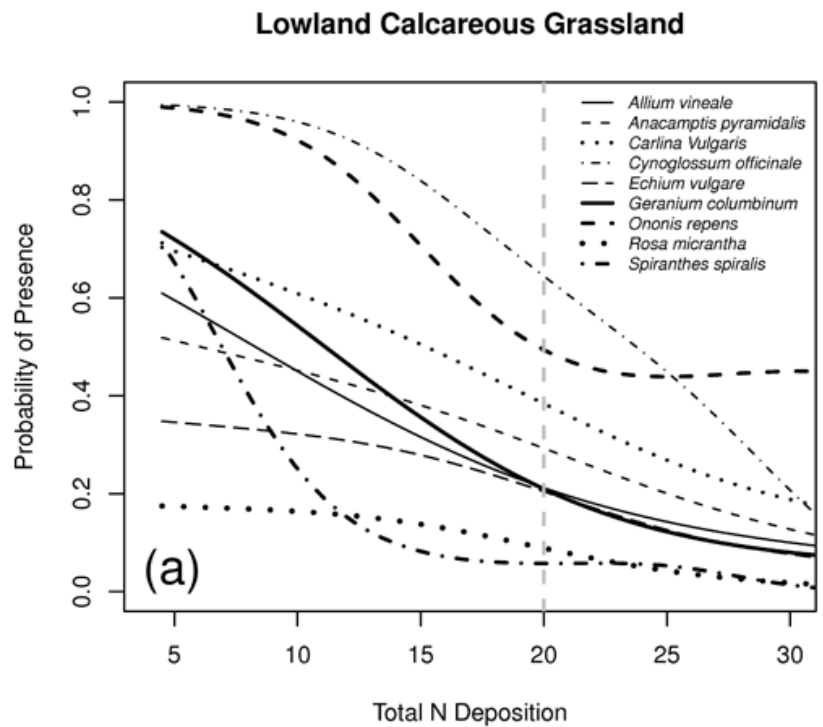

Lowland Calcareous Grassland

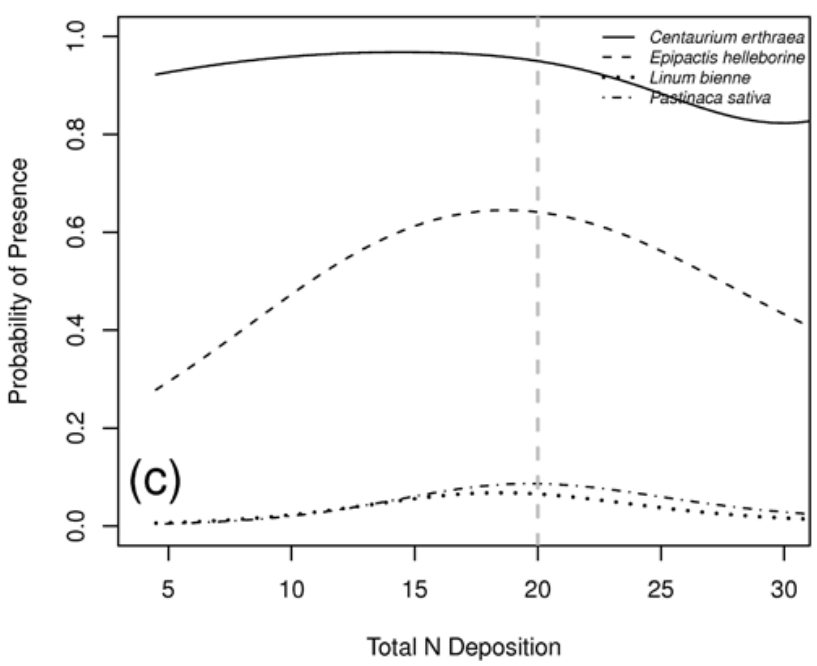

Lowland Calcareous Grassland

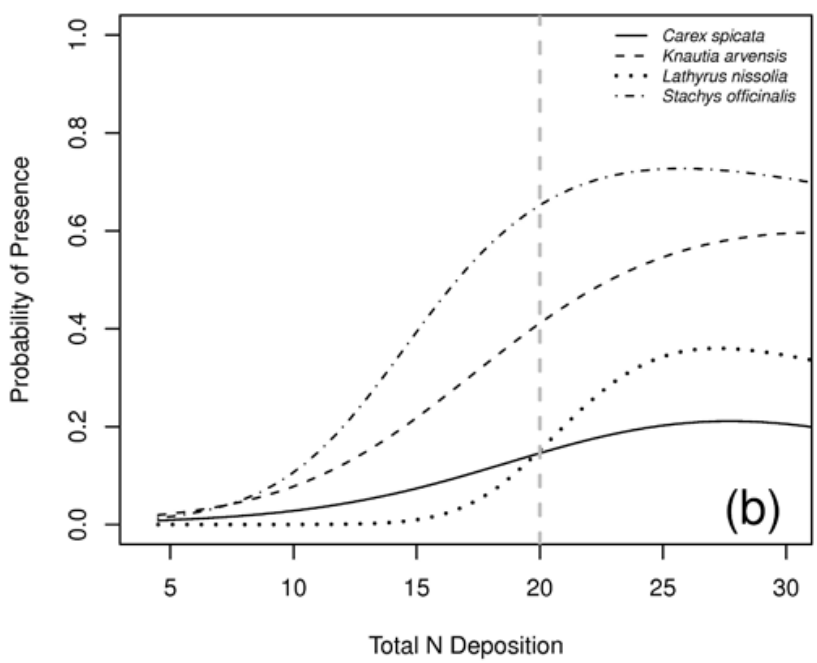

Upland Calcereous Grassland

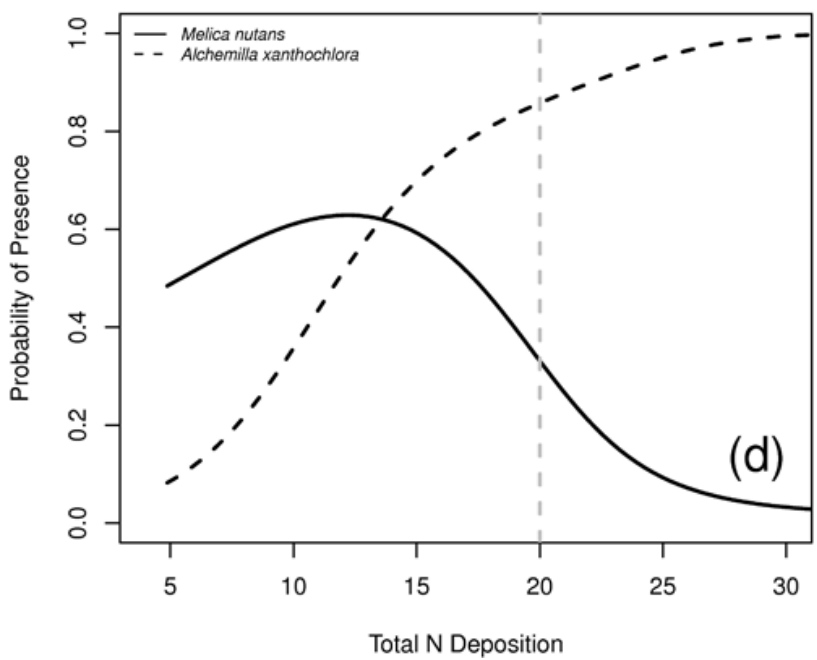

Fig. 2. Change in probability of presence for species showing statistically significant relationships to $\mathrm{N}$ deposition in calcareous grasslands in the Vascular Plant database against increasing total inorganic $\mathrm{N}$ deposition $\left(\mathrm{kg} \mathrm{N} \mathrm{ha}^{-1} \mathrm{yr}^{-1}\right)$. The dashed grey line indicates the midpoint of the critical load range for calcareous grasslands as defined by Bobbink and Hettelingh (2011).

\subsubsection{Acid grassland}

In the Vascular Plant Database there were sufficient data to test the probability of presence with $\mathrm{N}$ deposition for eleven species (between 10 and $90 \%$ of hectads occupied) for lowland acid grassland. Five of these species showed a significant relationship with $\mathrm{N}$ deposition: Cerastium arvense, Cerastium semidecandrum, Trifolium arvense, Vicia lathyroides and Viola canina. All five species showed similar trends (Fig. 4), with the probability of presence declining rapidly with increasing deposition, including at levels below the critical load of $12.5 \mathrm{~kg} \mathrm{~N} \mathrm{ha}^{-1} \mathrm{yr}^{-1}$, and then tailing off.
Only one species was investigated for upland acid grassland but did not show a significant response to $\mathrm{N}$ deposition.

In the BSBI data for lowland acid grasslands there was sufficient data on only one species in the data set (Appendix B), Senecio sylvaticus, which did not show a significant relationship with $\mathrm{N}$ deposition. For upland acid grassland again only one species had sufficient data for analysis: Agrostis vinealis. A. vinealis showed a significant hump-backed response to $\mathrm{N}$ deposition, increasing to $25 \mathrm{~kg} \mathrm{~N} \mathrm{ha}^{-1} \mathrm{yr}^{-1}$ then declining. 

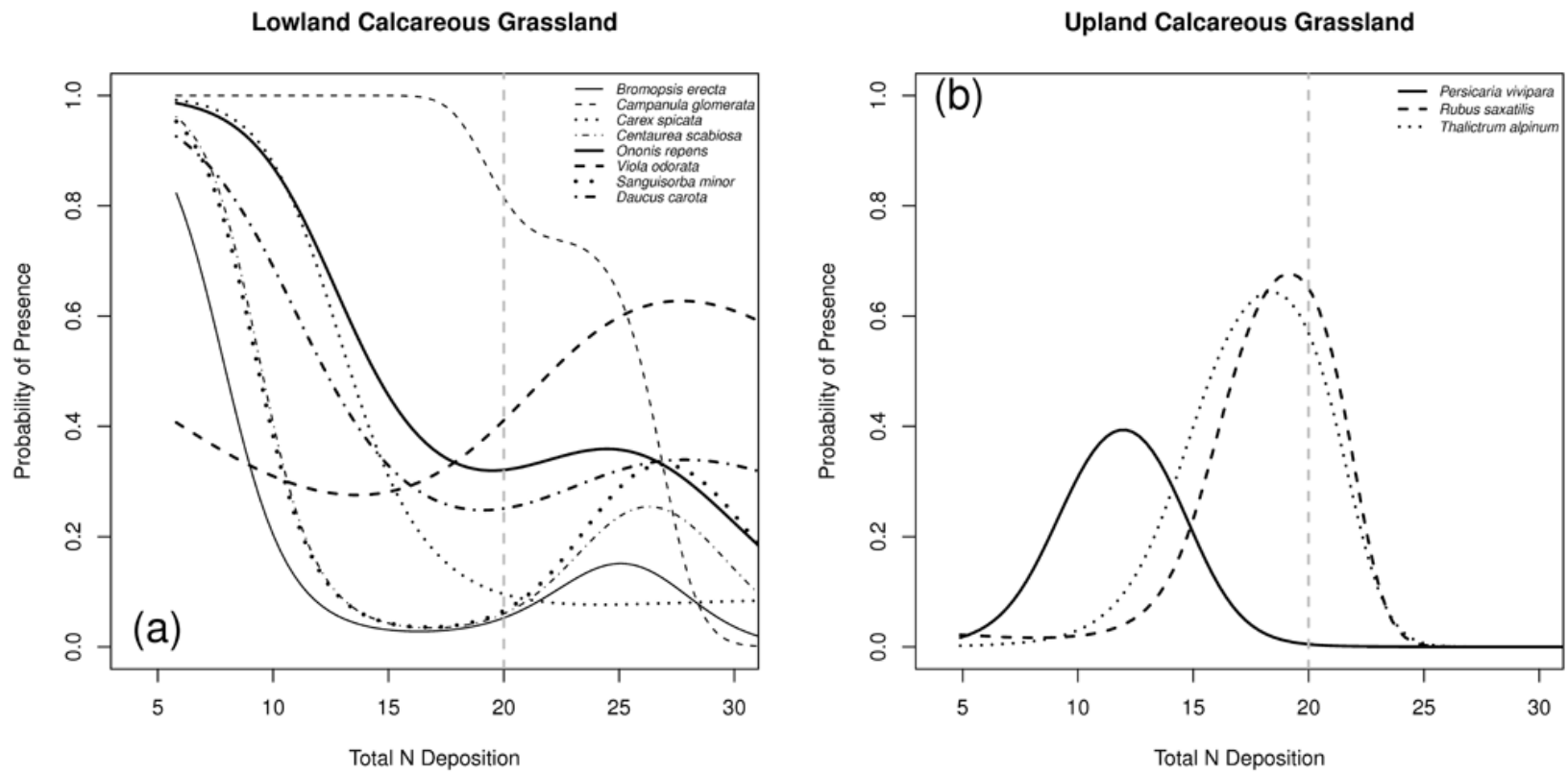

Fig. 3. Change in probability of presence for species showing statistically significant relationships to $\mathrm{N}$ deposition in calcareous grasslands in the BSBI local change survey data against increasing total inorganic $\mathrm{N}$ deposition $\left(\mathrm{kg} \mathrm{N} \mathrm{ha}^{-1} \mathrm{yr}^{-1}\right)$. The dashed grey line indicates the midpoint of the critical load range for calcareous grasslands as defined by Bobbink and Hettelingh (2011).

\subsubsection{Calcareous grassland}

In the Vascular Plant Database the presence/absence of 40 species in lowland calcareous grassland were modelled. Of these, 17 showed significant relationships with $\mathrm{N}$ deposition (Appendix B). Nine species showed negative relationships (Fig. 2a) with $\mathrm{N}$ deposition: Allium vineale, Anacamptis pyramidalis, Carlina vulgaris, Cynoglossum officinale, Echium vulgare, Geranium columbinum, Ononis repens, Rosa micrantha and Spiranthes spiralis. All of these species showed changes in their probability of presence even at low levels of $\mathrm{N}$ deposition well below the critical load of $20 \mathrm{~kg} \mathrm{Nha}^{-1} \mathrm{yr}^{-1}$. Four species showed positive relationships (Fig. 2b) with $\mathrm{N}$ deposition: Carex spicata, Knautia arvensis, Lathyrus nissolia and Stachys officinalis. All of which appeared to increase to around $25 \mathrm{~kg} \mathrm{Nha}^{-1} \mathrm{yr}^{-1}$ and then stabilise. There were also four species (Centaurium erythraea, Epipactis helleborine, Linum bienne and Pastinaca sativa) that showed hump-backed distributions (Fig. 2c) with the peak occurring around the critical load level. For upland calcareous grasslands there were only sufficient data to analyse seven species. Two species showed significant relationships with $\mathrm{N}$ deposition (Fig. 2d). Alchemilla xanthochlora showed a significant increase with $\mathrm{N}$ deposition, whereas Melica nutans showed a generally declining probability of presence with increasing $\mathrm{N}$ deposition. The slight increase at low levels of deposition is due to the wide variation in the data at this point.

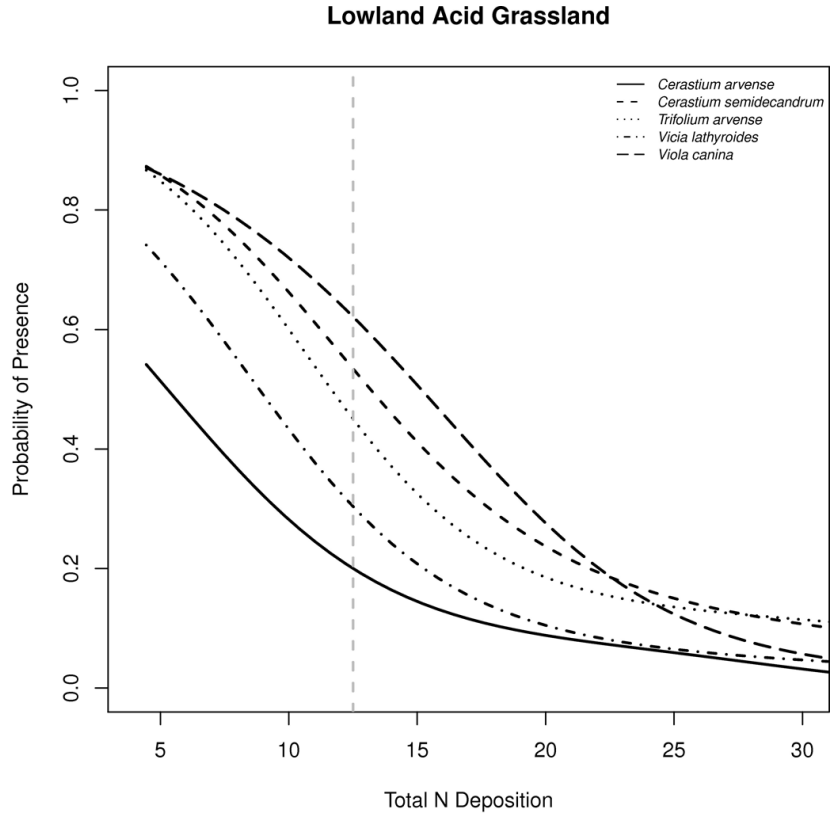

Fig. 4. Change in probability of presence for species showing statistically significant relationships to $\mathrm{N}$ deposition in lowland acid grasslands in the Vascular Plant database against increasing total inorganic $\mathrm{N}$ deposition $\left(\mathrm{kg} \mathrm{Nha}^{-1} \mathrm{yr}^{-1}\right)$. The dashed grey line indicates the midpoint of the critical load range for acid grasslands as defined by Bobbink and Hettelingh (2011). 

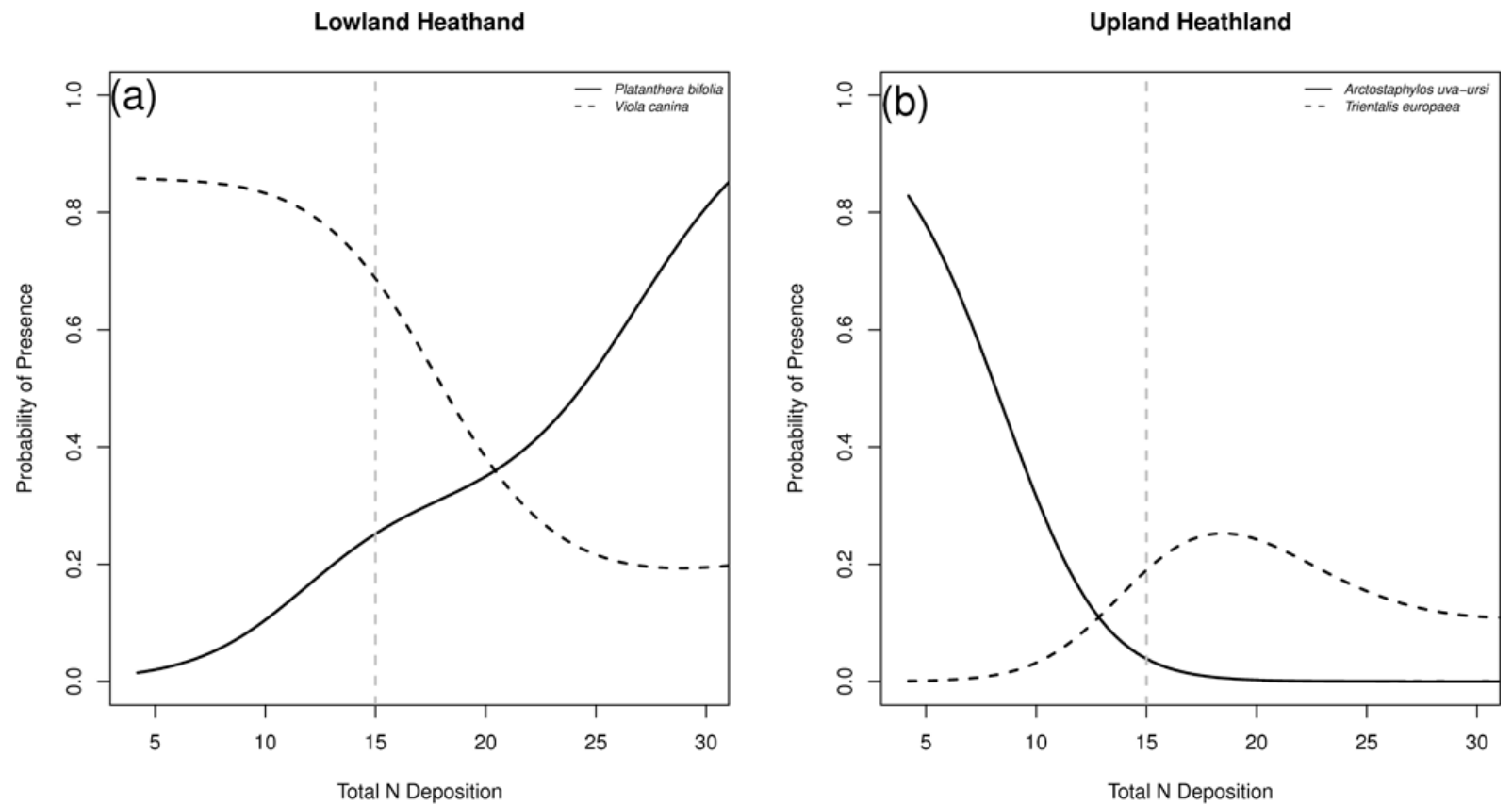

Fig. 5. Change in probability of presence for species showing statistically significant relationships to $\mathrm{N}$ deposition in heathland in the Vascular Plant database against increasing total inorganic $\mathrm{N}$ deposition $\left(\mathrm{kg} \mathrm{Nha}^{-1} \mathrm{yr}^{-1}\right)$. The dashed grey line indicates the midpoint of the critical load range for heathlands as defined by Bobbink and Hettelingh (2011).

In the BSBI local change survey data there were sufficient records for analysis of 17 species within lowland calcareous grasslands. Eight showed a significant relationship with $\mathrm{N}$ deposition (Fig. 3a): Bromopsis erecta, Campanula glomerata, Carex spicata, Centaurea scabiosa, Daucus carota, Ononis repens, Sanguisorba minor and Viola odorata. Of these, a number of species show changes of a small magnitude or complex responses but there are clear, steep declines for a number of species including $B$. erecta, $C$. glomerata, $C$. spicata and $O$. repens. There were 12 species analysed in upland calcareous grasslands of which three species showed significant correlations with $\mathrm{N}$ deposition: Persicaria vivipara, Rubus saxatilis and Thalictrum alpinum. All of these species showed hump-backed relationships with $\mathrm{N}$ deposition (Fig. 3b).

\subsubsection{Heathland}

Within the Vascular Plant Database there was sufficient data for analysis of four species in lowland heathland. Two species showed a significant relationship with $\mathrm{N}$ deposition (Fig. 5a). Platanthera bifolia had a positive relationship with $\mathrm{N}$ deposition, with probability of presence increasing steadily as $\mathrm{N}$ deposition increased. Viola canina had a negative relationship with $\mathrm{N}$ deposition declining considerably in its probability of presence between 10 and $25 \mathrm{~kg} \mathrm{Nha}^{-1} \mathrm{yr}^{-1}$. In upland heathlands it was possible to analyse ten species (Appendix B). Two species showed significant relationships with $\mathrm{N}$ deposition. Arctostaphylos uva-

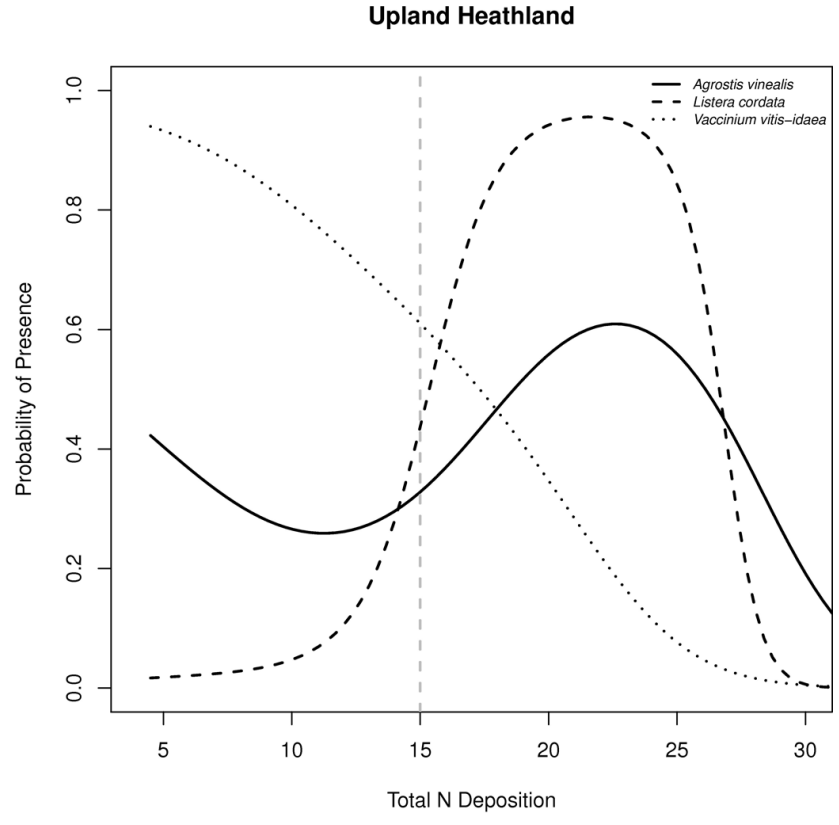

Fig. 6. Change in probability of presence for species showing statistically significant relationships to $\mathrm{N}$ deposition in upland heathland in the BSBI local change survey data against increasing total inorganic $\mathrm{N}$ deposition $\left(\mathrm{kg} \mathrm{N} \mathrm{ha}^{-1} \mathrm{yr}^{-1}\right)$. The dashed grey line indicates the midpoint of the critical load range for heathlands as defined by Bobbink and Hettelingh (2011). 

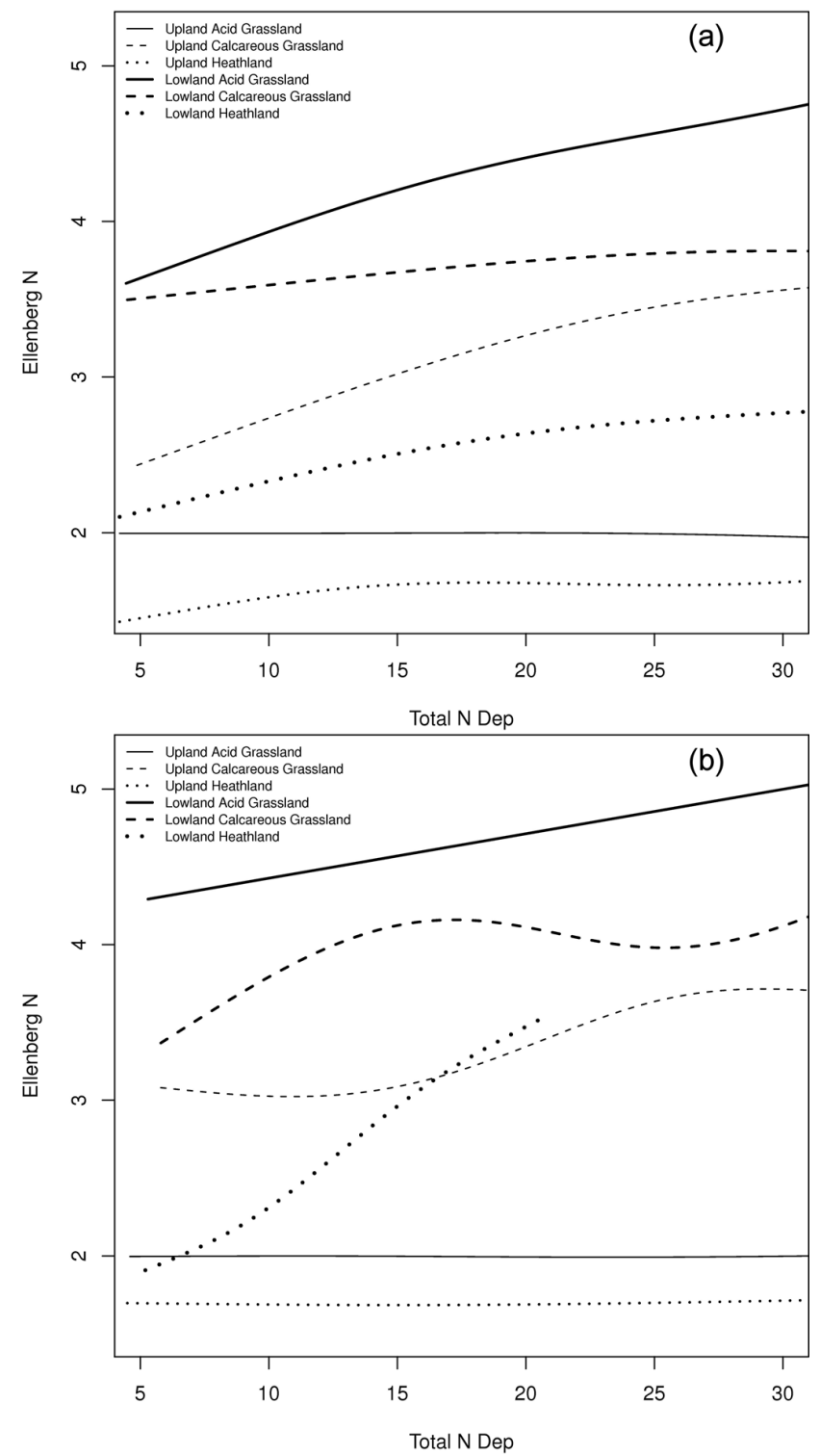

Fig. 7. Modelled response of Ellenberg $\mathrm{N}$ scores against total inorganic $\mathrm{N}$ deposition $\left(\mathrm{kg} \mathrm{N} \mathrm{ha}^{-1} \mathrm{yr}^{-1}\right)$ using data from (a) the Vascular Plant database and (b) the BSBI local change survey.

ursi had a negative relationship with $\mathrm{N}$ deposition declining in probability of presence up to $15 \mathrm{~kg} \mathrm{Nha}^{-1} \mathrm{yr}^{-1}$ and then remaining at very low levels (Fig. 5b). Trientalis europaea showed a hump-backed distribution peaking at approximately $18 \mathrm{~kg} \mathrm{Nha}^{-1} \mathrm{yr}^{-1}$.

In the BSBI Local Change survey data there were insufficient data to perform analysis on any of the 16 potential lowland heathland species in the data set. However, in upland heathland there were seven species for which analysis could be performed (Appendix B). Of these, three showed significant relationships with $\mathrm{N}$ deposition: A. vinealis, Listera cordata and Vaccinium vitis-idaea (Fig. 6). A. vinealis and L. cordata showed similar hump-backed responses with peak probability of presence at around $20 \mathrm{~kg} \mathrm{Nha}^{-1} \mathrm{yr}^{-1}$, whereas $V$. vitis-idaea showed a clear decline in response to $\mathrm{N}$ deposition.

\subsection{Ellenberg N}

Plots of modelled relationships between Ellenberg $\mathrm{N}$ score and total inorganic $\mathrm{N}$ deposition for all habitats are shown in Fig. 7a for the Vascular Plant database and Fig. 7b for the BSBI Local change survey data.

Using data from the Vascular Plant Database, average Ellenberg $\mathrm{N}$ scores showed a clear increase with increasing $\mathrm{N}$ deposition (indicating an increase in fertility) for lowland acid grasslands $(p=0.0005)$. For upland acid grasslands, however, there was no significant ( $p=0.32$ ) relationship between Ellenberg $\mathrm{N}$ and $\mathrm{N}$ deposition. This result was echoed in the analysis of the BSBI Local Change survey data, showing a clear increase in the lowlands $(p=0.01)$, but no significant result in the upland acid grasslands $(p=0.42)$.

There were significant results for both lowland $(p=$ $0.004)$ and upland $(p=0.0062)$ calcareous grasslands in the analysis of Ellenberg $\mathrm{N}$ scores from the Vascular Plant Database with both communities showing a significant increase in mean Ellenberg $\mathrm{N}$ with increasing $\mathrm{N}$ deposition. Results from the BSBI Local Change survey data in upland calcareous grasslands showed no significant relationship between $\mathrm{N}$ deposition and mean Ellenberg $\mathrm{N}$ score $(p=0.72)$, whereas lowland calcareous grassland showed a significant $(p=0.0074)$ increase. Unlike the acid grasslands analysis however this relationship is non-linear.

Analysis of the vascular plant database for both upland and lowland heathlands showed a significant $(p=0.0059$ and $p=0.0549$, respectively) increase in Ellenberg $\mathrm{N}$ score. The analysis of BSBI Local Change survey data for heathlands showed mixed results between upland and lowland communities with no significant response for the analysis of upland heathland ( $p=0.98)$ but a clear, significant ( $p=0.0015)$ increase in Ellenberg $\mathrm{N}$ with increasing deposition for lowland heathland.

\section{Discussion}

\subsection{Individual species responses}

\subsubsection{Acid grassland}

For lowland acid grassland, consistent trends were found in the Vascular Plant Database with five species displaying significant responses showing a very similar negative relationship, declining in occupancy to low levels before stabilising ca. $25 \mathrm{~kg} \mathrm{Nha}^{-1} \mathrm{yr}^{-1}$. With the exception of Viola canina, which the BSBI Local Change survey results (Braithwaite et al., 2006) suggested was declining due to its vulnerability to eutrophication, all are small, low-growing or prostrate species most typical of dry acid grassland in the 
Acid Grassland

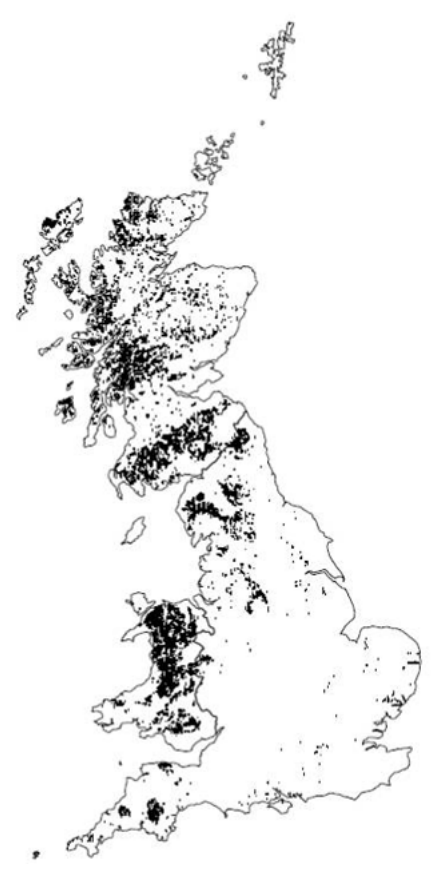

Calcareous Grassland

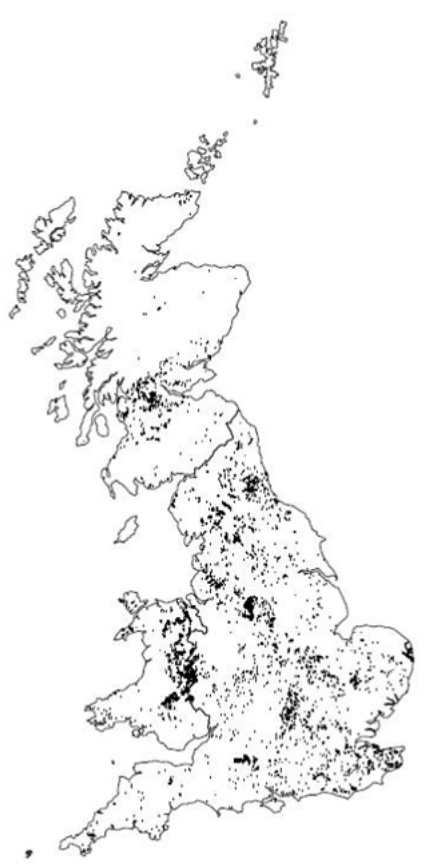

Heathland

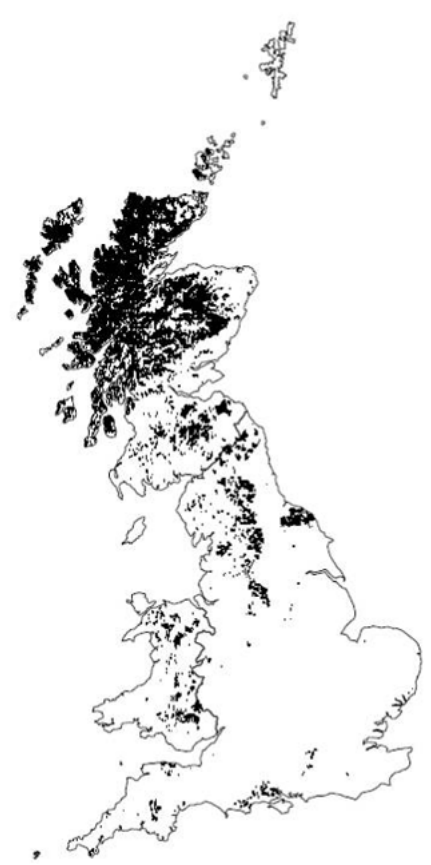

Fig. 8. Distribution of three semi-natural habitats: calcareous grassland; acid grassland; and heathland over Great Britain according to Land Cover Map 2000. Shown and mapped at $1 \mathrm{~km}^{2}$ resolution when habitat was dominant type in the $1 \mathrm{~km}$ square.

south and east of England. All have low Ellenberg $\mathrm{N}$ values and thus are typical of infertile environments. Unfortunately, there were no species with suitable coverage (between 10 and $90 \%$ occupancy) in the BSBI Local Change survey data to test the effects of $\mathrm{N}$ deposition and to enable us to confirm whether there were consistent trends among species within tetrads that contained lowland acid grassland. It is difficult to draw conclusions for upland acid grassland as only Agrostis vinealis displayed a significant (hump-backed) response reaching an optimum in occupancy at ca. $25 \mathrm{~kg} \mathrm{Nha}^{-1} \mathrm{yr}^{-1}$ in the BSBI Local Change survey data.

\subsubsection{Calcareous grassland}

Results for the lowland calcareous grassland analysis using the Vascular Plant data showed that around half the species with significant responses showed negative trends in occupancy in relation to increasing $\mathrm{N}$ deposition. The BSBI Local Change survey data also showed a high proportion of negative trends, though this was generally for different species than noted in the Vascular plant data. Although the two datasets had numerous species in common, only one species, the legume Ononis repens, showed a significant negative response in both. For most other cases when a particular species was recorded in both datasets, a significant result in one was paired with a non-significant result in the other. This could be because although a particular species was recorded in the two datasets, it may not correspond to records from the same locations. This could have a large effect in a spatial modelling approach as adopted here.

It was notable that most species displaying clear negative trends (in either dataset) tended to be specialists of grazed nutrient-poor calcareous grassland in Great Britain and generally showed declines in the BSBI Local Change survey results (Braithwaite et al., 2006) e.g. Bromopsis erecta, Campanula glomerata, Carlina vulgaris, Spiranthes spiralis. These were typically species with low Ellenberg $\mathrm{N}$ values. Species displaying more complex (hump-backed) or positive trends in the Vascular Plant Database dataset are generally more typical of taller and slightly more mesotrophic swards (e.g. Epipactis helleborine, Knautia arvensis, Lathyrus nissolia, Stachys officinalis). Increased biomass production following increased $\mathrm{N}$ deposition would therefore favour the latter species and may partly account for the reported declines of some of the rarer species dependent on shorter swards. Carex spicata, which also showed a positive relationship to $\mathrm{N}$ deposition, was found to have increased in the BSBI Local Change Survey results (Braithwaite et al., 2006), which suggested that increases were potentially a result of increased availability in gaps of drought-prone grasslands and verges.

In upland calcareous grassland, Melica nutans was the only species to show a clear negative relationship with $\mathrm{N}$, whereas Alchemilla xanthochlora had greatest probability of 
occurrence at the highest $\mathrm{N}$ deposition levels. Melica nutans was shown to decline in the BSBI Local Change survey results (Braithwaite et al., 2006), possibly due to competition. Alchemilla xanthochlora was also shown to decline in the BSBI Local Change survey results (Braithwaite et al., 2006), possibly a result of eutrophication. These results found by Braithwaite et al. (2006) were obtained from pooling data over multiple habitats, whereas the relationship we find is based solely on upland calcareous grasslands. It is typically a species of unimproved hay meadows yet is capable of surviving in tall-herb communities on roadsides. Three species displayed a hump-backed relationship to $\mathrm{N}$ deposition in the BSBI Local Change survey data, with an optimum in occupancy between $10-20 \mathrm{~kg} \mathrm{~N} \mathrm{ha}^{-1} \mathrm{yr}^{-1}$ (Persicaria vivipara, Rubus saxatilis, Thalictrum alpinum). Again these results are difficult to interpret but may represent the localised distribution of these species to a narrow altitudinal and geographical range in the uplands, and therefore a highly restricted $\mathrm{N}$ deposition gradient, or a potential unmodelled interaction between $\mathrm{N}$ deposition and another covariate in the model.

\subsubsection{Heathland}

In the Vascular Plant Database, only two species displayed significant trends for lowland heath, Viola canina decreasing and Platanthera bifolia increasing significantly in probability of presence with increasing $\mathrm{N}$ deposition. $V$. canina is a species with a low Ellenberg $\mathrm{N}$ score and its low stature means it does not compete well with competitive species. The latter result is very surprising as $P$. bifolia is an uncommon plant of unimproved pastures and wet heathlands. It was shown to be declining in the BSBI Local Change survey results (Braithwaite et al., 2006), which they suggest was due to a long term response to management of moorland for grouse. Having applied the habitat masks, there were no species in lowland heathland recorded in the BSBI Local Change survey data that had sufficient coverage (between 10 and $90 \%$ occupancy) to allow testing of the spatial effects of $\mathrm{N}$ deposition.

The results for upland heathland showed two sub-shrubs Arctostaphylos uva-ursi (Vascular Plant Database) and Vaccinium vitis-idaea (BSBI Local Change survey data) displaying clear negative trends in occupancy with increasing $\mathrm{N}$ deposition. Both of these species have low Ellenberg $\mathrm{N}$ values. Two species associated with more humid upland heathlands, Trientalis europaeus and Listera cordata, displayed distinct optima at around $20 \mathrm{~kg} \mathrm{~N} \mathrm{ha}^{-1} \mathrm{yr}^{-1}$, possibly reflecting their restricted distributions along the $\mathrm{N}$ deposition gradient. Both are elusive species. An alternative hypothesis for Listera cordata might be its dependence on aerial deposition of nutrients for growth in nutrient-poor habitats. This species typically roots within Sphagnum tussocks and therefore attains most of its nutrients from decaying matter or rainwater.

\subsection{Ellenberg $N$}

There was a general trend for higher Ellenberg $\mathrm{N}$ scores in areas of high $\mathrm{N}$ deposition across many habitats indicating higher fertility rates. The most prominent changes occurred in lowland acid grasslands, where Ellenberg $\mathrm{N}$ showed this relationship in both data sets. However, the magnitude of these differences across the $\mathrm{N}$ deposition gradient were generally quite small - differences of approximately one unit on the Ellenberg $\mathrm{N}$ scale between deposition of 5 and $30 \mathrm{~kg} \mathrm{Nha}^{-1} \mathrm{yr}^{-1}$. It is somewhat surprising that lowland grasslands appear to show greater differences than upland ones. Due to their tendency to have soils with a lower nutrient status, we might expect upland grasslands to be more sensitive. Although this is dependent on the species present being capable of exploiting any excess N. For upland acid grasslands the lack of a convincing Ellenberg $\mathrm{N}$ score response to $\mathrm{N}$ deposition is not entirely surprising as this has also been found in research scale spatial surveys which have suggested acidification from $\mathrm{N}$ deposition may be the main driver of reductions in species richness rather than eutrophication (Maskell et al., 2010; Stevens et al., 2010).

The two datasets generally show consistent results between the habitats with only slight differences in the shape of the response, whilst the general pattern and modelled scores are broadly aligned.

\subsection{Ecosystem effects}

Whilst deletions of rare species and additions of generalist species constitute changes in conservation value, impacts on ecosystem properties can also result. These impacts can often be understood in terms of the mass effect of dominant species in controlling productivity and litter quality, coupled with the functional diversity effect of subordinate species (Grime, 1998; Smith and Knapp, 2003; Laughlin, 2011). Because the scale of our observational data was occupancy of large grid cells $(10 \times 10 \mathrm{~km}$ and $2 \times 2 \mathrm{~km})$ common generalists and many ecosystem dominants were not examined since they are either not specialised to those focal habitats vulnerable to nitrogen deposition or were likely to be present in many grid squares and so insensitive to the nitrogen deposition gradient. However, a number of the species for which we found significant relationships are either habitat dominants or possess traits known to be influential in controlling ecosystem function. For example three leguminous $\mathrm{N}$-fixers showed negative responses to the nitrogen gradient. This could indicate a loss of capacity to fix $\mathrm{N}$ and sequester carbon, yet two of the three species, Vicia lathyroides and Trifolium arvense, are not common and, where they do occur, occupy subordinate positions in the dominance hierarchies of each grassland type. Community dominants include Tricophorum cespitosum (upland heath), Vaccinium vitis-idaea (upland heath) and Bromopsis erecta (lowland calcareous grassland). Their negative relationships with $\mathrm{N}$ deposition 
imply a potentially more significant loss of function. This situation is more likely for populations at their range edge.

Most of the species for which significant effects were found are of restricted distribution in Britain and at low biomass even within their favoured habitat. On this basis, their changing abundance may have had less direct impact on ecosystem function than correlated increases in biomass of species that may have responded positively to increased nutrient supply. The impact of increasing species is likely to be significant both in terms of their role in competitive suppression of shorter, stress-tolerators and in driving influential changes in ecosystem productivity and nutrient cycling. The scale of the study makes it difficult to speculate further on ecosystem impacts since losses or gains from survey squares are likely to exhibit large lag effects relative to influential changes in biomass. This also means that biomass-linked changes in function may well have either significantly predated loss from the grid cell or, for additions, should follow subsequently if colonisation precedes biomass increase. Because of the subordinate position of many of these species in their favoured habitat, it may be that ecosystem impacts have been or will be relatively minor and that observed species changes are most significant in terms of loss of the cultural ecosystem service linked to the conservation of wild species diversity. However, recent work has helped elucidate the supporting role of a diverse species pool in maintaining ecosystem function (Isbell et al., 2011). We cannot therefore, rule out the possibility of reduced resilience following species deletions among the ecosystems studied here.

\section{Conclusions}

This study set out to evaluate the response of individual vascular plant species to $\mathrm{N}$ deposition and assess how the shape and direction of any relationships relate to current critical load levels. After accounting for a number of additional explanatory variables, we have found evidence that a number of species show clear responses to $\mathrm{N}$ even at low levels. Although the models allow for the possibility of no change up to a threshold after which we see a decline, there are few instances where this is indeed the case. Where we do see significant relationships to $\mathrm{N}$ deposition, there are many changes that occur well below the critical load, with Ellenberg $\mathrm{N}$ values increasing from the lowest $\mathrm{N}$ levels and some species showing strong responses at low deposition. This highlights the possibility that current European empirical critical loads for $\mathrm{N}$ do not protect all species and this gives concern in respect of meeting nature, conservation and biodiversity targets of the UK and Europe. Ongoing effects are also found above critical load values indicating there may be benefits from reductions in deposition however small and at any level. Within all three habitats, there are a number of species with low Ellenberg $\mathrm{N}$ values, which may have been expected to respond negatively to $\mathrm{N}$ deposition but do not show a significant relationship with $\mathrm{N}$ deposition here. This may be for a number of reasons as this analysis is based on data using large recording units, there may be interactions with climate not detected and presence absence data may be too coarse and insensitive to change. Abundance of individual species would be more sensitive to change but targeted surveys are needed to collect such data. The main benefits of using a large scale study with comprehensive nationwide coverage, as done here, are that we have good coverage over the $\mathrm{N}$ deposition gradient with which to build our models, any inference drawn is not spatially restricted and there is no chance that we only model an unusual niche of a given species.

However, using large scale data and large recording units meant that the assignment of species to a habitat was at a coarse scale and may not be as accurate as smaller scale data and smaller recording units such as quadrats, which contain species data from known habitat types. It is also important to note that the analysis presented did not extend to species which were too rare or too abundant. We were therefore only working with the middle range of species and conclusions are based on modelling these species. It may be, however, that the rare or abundant species show more sensitive changes or differing relationships to those presented here. This may be an avenue of further research, as would be the investigation of other drivers variables and the possibility of including interaction terms to look at 2 dimensional species responses.

To ensure that relationships seen here did not reflect a potential correlation between $\mathrm{N}$ deposition and habitat area, the theory being that the larger the habitat area the more likely we are to find a record, some selected species were re-modelled with habitat area included as an additional covariate in the model. However, no differences to the original analysis were found and the plotted relationships remained unchanged.

Our work has sought to separate out the effect of $\mathrm{N}$ deposition from other variables known to affect the responses of interest. To this end we included in the model all extra variables we thought ecologically meaningful and for which data were available. We also included a generic spatial surface and used a flexible class of models. All of which mean we have made less assumptions, are less open to bias and have accounted for more possible confounding issues than any other similar study. We therefore see this as a key contribution to a growing body of scientific evidence suggesting species level impacts in all three habitats investigated and potential effects at low deposition values beneath current critical load levels. 


\section{Appendix A}

Habitat specific $\mathbf{N}$ deposition ranges
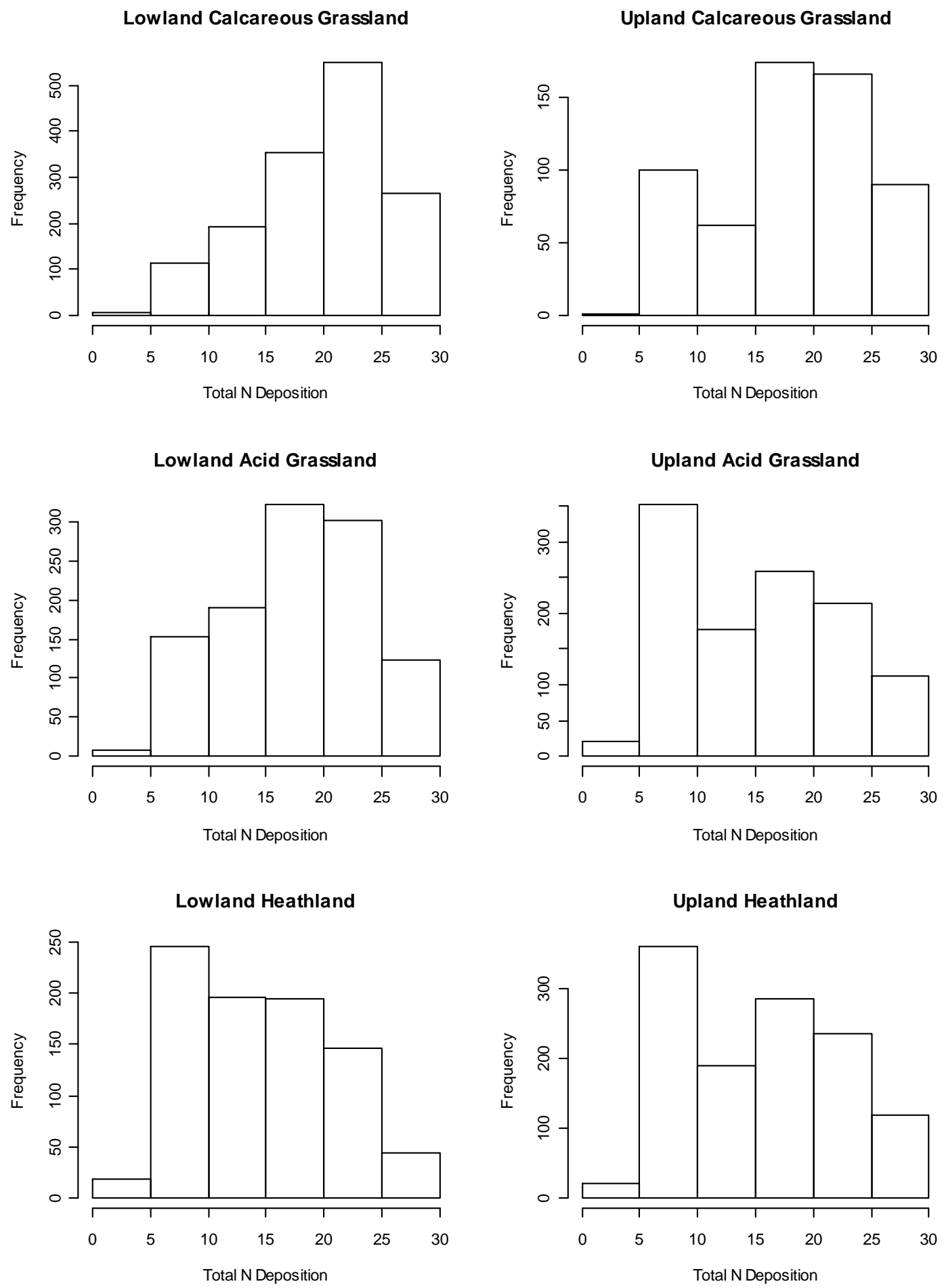

Fig. A1. Histograms showing the distribution of $\mathrm{N}$ deposition in the Vascular plant database between $0-30 \mathrm{~kg} \mathrm{Nha}^{-1} \mathrm{yr}^{-1}$. 
Lowland Calcareous Grassland

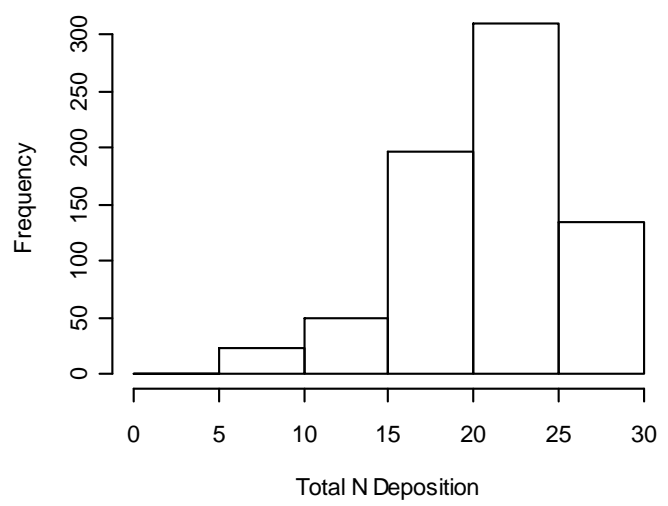

Lowland Acid Grassland

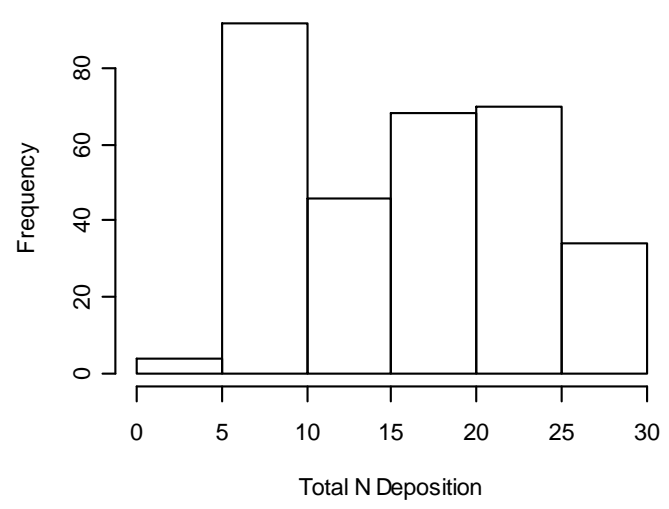

Lowland Heathland

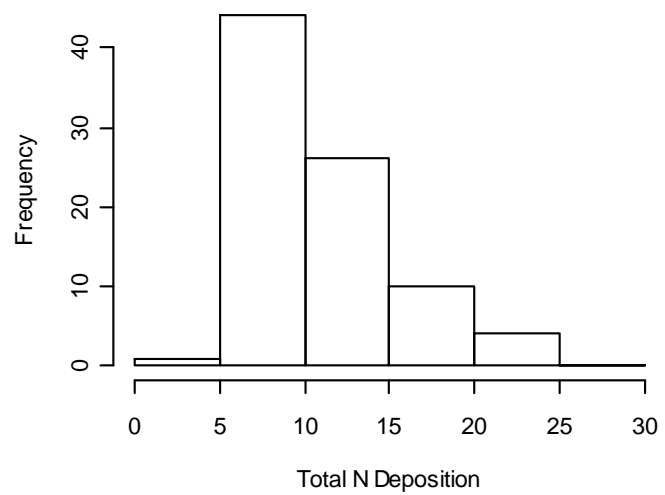

Upland Calcareous Grassland

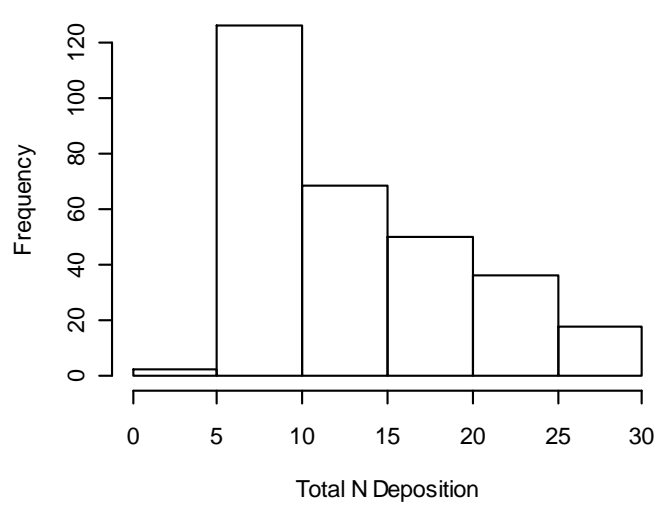

Upland Acid Grassland

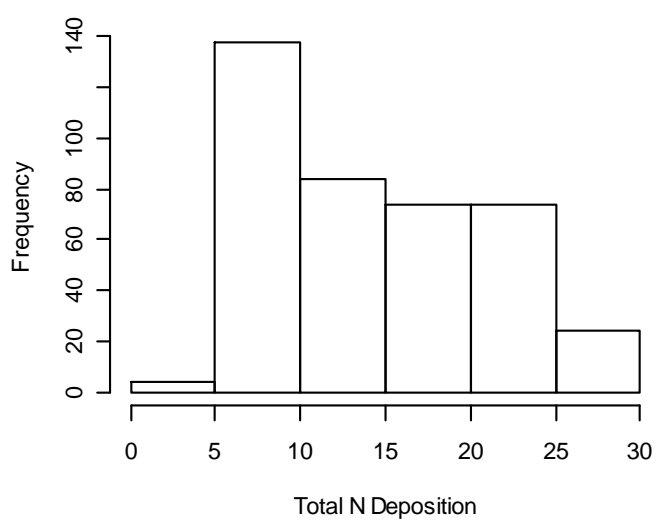

Upland Heathland

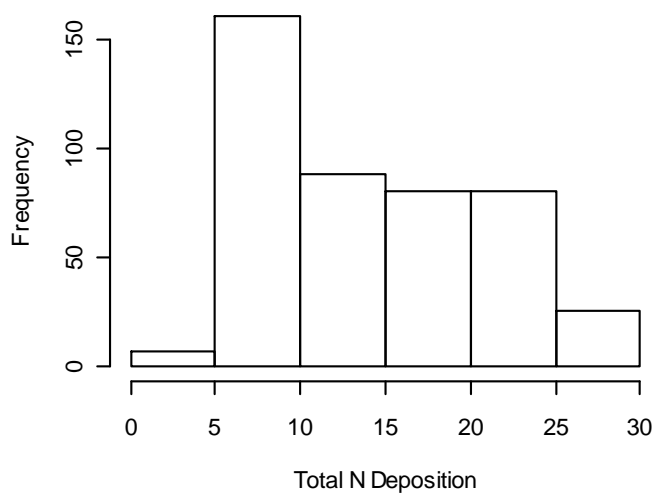

Fig. A2. Histograms showing the distribution of $\mathrm{N}$ deposition in the BSBI local change survey data between $0-30 \mathrm{~kg} \mathrm{Nha}^{-1} \mathrm{yr}^{-1}$. 


\section{Appendix B}

\section{All species results}

Table B1. Full table of results showing the p-values testing the null hypothesis that there is no relationship between species occurrence and $\mathrm{N}$ deposition. Significant results are highlighted.

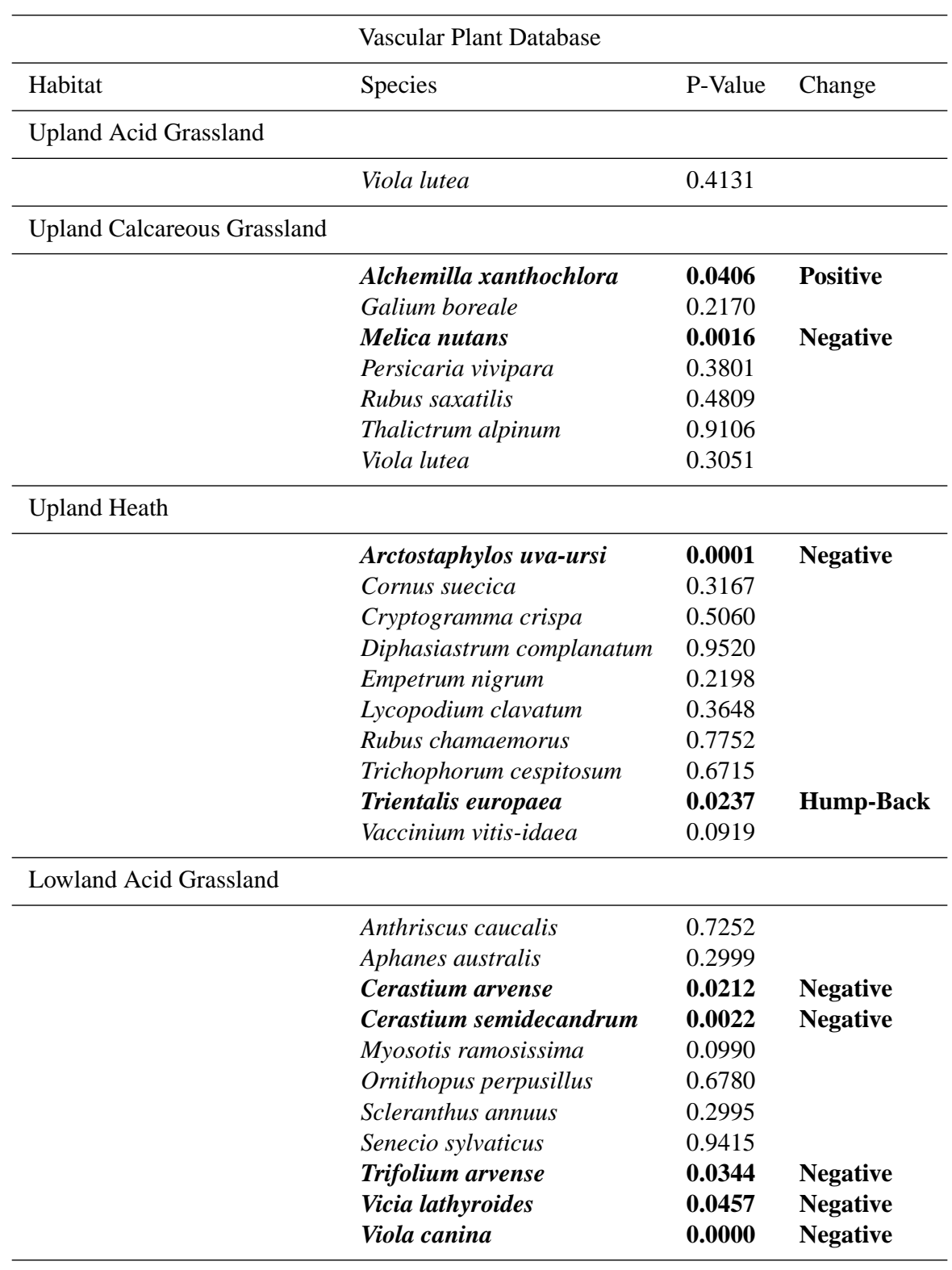


Table B1. Continued.

\begin{tabular}{|c|c|c|c|}
\hline Lowland Calcareous Grassland & & & \\
\hline & Allium vineale & 0.0365 & Negative \\
\hline & Anacamptis pyramidalis & 0.0507 & \\
\hline & Blackstonia perfoliata & 0.0571 & \\
\hline & Brachypodium pinnatum & 0.2820 & \\
\hline & Bromopsis erecta & 0.8306 & \\
\hline & Carex spicata & 0.0478 & Positive \\
\hline & Carlina vulgaris & 0.0226 & Negative \\
\hline & Catapodium rigidum & 0.7550 & \\
\hline & Centaurium erythraea & 0.0087 & Hump-Back \\
\hline & Centaurea scabiosa & 0.8592 & \\
\hline & Cirsium acaule & 0.5282 & \\
\hline & Cirsium eriophorum & 0.0905 & \\
\hline & Clinopodium vulgare & 0.2215 & \\
\hline & Cynoglossum officinale & 0.0000 & Negative \\
\hline & Daucus carota & 0.2341 & \\
\hline & Echium vulgare & 0.0070 & Negative \\
\hline & Epipactis helleborine & 0.0280 & Hump-Back \\
\hline & Filago vulgaris & 0.1019 & \\
\hline & Geranium columbinum & 0.0176 & Negative \\
\hline & Geranium sanguineum & 0.1388 & \\
\hline & Hypericum hirsutum & 0.1314 & \\
\hline & Inula conyzae & 0.0880 & \\
\hline & Knautia arvensis & 0.0014 & Positive \\
\hline & Lathyrus nissolia & $\mathbf{0 . 0 0 3 0}$ & Positive \\
\hline & Linum bienne & 0.0306 & Hump-Back \\
\hline & Ononis repens & 0.0109 & Negative \\
\hline & Ononis spinosa & 0.6074 & \\
\hline & Ophrys apifera & 0.1344 & \\
\hline & Orchis morio & 0.2136 & \\
\hline & Origanum vulgare & 0.2222 & \\
\hline & Pastinaca sativa & 0.0154 & Hump-Back \\
\hline & Picris hieracioides & 0.4054 & \\
\hline & Poa angustifolia & 0.9579 & \\
\hline & Rosa micrantha & 0.0105 & Negative \\
\hline & Rosa rubiginosa & 0.3157 & \\
\hline & Sanguisorba minor & 0.1927 & \\
\hline & Sherardia arvensis & 0.3197 & \\
\hline & Spiranthes spiralis & 0.0074 & Negative \\
\hline & Stachys officinalis & 0.0186 & Positive \\
\hline & Viola odorata & 0.3596 & \\
\hline \multicolumn{4}{|l|}{ Lowland Heath } \\
\hline & Platanthera bifolia & 0.0081 & Positive \\
\hline & Radiola linoides & 0.0527 & \\
\hline & Scleranthus annuus & 0.6258 & \\
\hline & Viola canina & 0.0008 & Negative \\
\hline
\end{tabular}


Table B1. Continued.

\begin{tabular}{|c|c|c|c|}
\hline \multicolumn{4}{|c|}{ BSBI Local Change Survey Database } \\
\hline Habitat & Species & P-Value & Change \\
\hline \multicolumn{4}{|c|}{ Upland Acid Grassland } \\
\hline & Agrostis vinealis & 0.0060 & Hump-Back \\
\hline \multicolumn{4}{|c|}{ Upland Calcareous Grassland } \\
\hline & Alchemilla alpina & 0.2052 & \\
\hline & Galium boreale & 0.7008 & \\
\hline & Persicaria vivipara & 0.0001 & Hump-Back \\
\hline & Rubus saxatilis & 0.0321 & Hump-Back \\
\hline & Saxifraga aizoides & 0.2127 & \\
\hline & Saxifraga oppositifolia & 0.1236 & \\
\hline & Selaginella selaginoides & 0.0605 & \\
\hline & Thalictrum alpinum & 0.0231 & Hump-Back \\
\hline \multicolumn{4}{|c|}{ Upland Heath } \\
\hline & Agrostis vinealis & 0.0206 & Hump-Back \\
\hline & Arctostaphylos uva-ursi & 0.1448 & \\
\hline & Listera cordata & 0.0001 & Hump-Back \\
\hline & Lycopodium clavatum & 0.0880 & \\
\hline & Rubus chamaemorus & 0.0707 & \\
\hline & Trichophorum cespitosum & 0.0701 & \\
\hline & Vaccinium vitis-idaea & 0.0074 & Negative \\
\hline \multicolumn{4}{|c|}{ Lowland Acid Grassland } \\
\hline & Senecio sylvaticus & 0.1240 & \\
\hline \multicolumn{4}{|c|}{ Lowland Calcareous Grassland } \\
\hline & Brachypodium pinnatum & 0.4144 & \\
\hline & Bromopsis erecta & 0.0052 & Negative \\
\hline & Campanula glomerata & 0.0000 & Negative \\
\hline & Carex spicata & 0.0183 & Negative \\
\hline & Catapodium rigidum & 0.1609 & \\
\hline & Centaurea scabiosa & 0.1047 & \\
\hline & Centaurium erythraea & 0.0000 & Negative \\
\hline & Crepis capillaris & 0.2595 & \\
\hline & Daucus carota & 0.0218 & Negative \\
\hline & Knautia arvensis & 0.1527 & \\
\hline & Ononis repens & 0.0021 & Negative \\
\hline & Origanum vulgare & 0.5387 & \\
\hline & Pastinaca sativa & 0.9980 & \\
\hline & Salvia verbenaca & 0.4535 & \\
\hline & Sanguisorba minor & 0.0000 & Negative \\
\hline & Stachys officinalis & 0.0962 & \\
\hline & Viola odorata & 0.0251 & Hump-Back \\
\hline
\end{tabular}


Acknowledgements. This work was funded by Defra, Joint Nature Conservation Committee (JNCC), Natural England, Scottish Natural Heritage and the Countryside Council for Wales. We are very grateful to the BSBI and Biological Records Centre for providing access to their database and to all the botanical recorders who have collected these data over many years. We are also grateful to $\mathrm{CEH}$ Edinburgh for providing $\mathrm{N}$ and $\mathrm{S}$ deposition data.

Edited by: S. Reis

\section{References}

Akaike, H.: Fitting autoregressive models for prediction, Ann. I. Stat. Math., 21, 243-247, 1969.

Bobbink, R. and Hettelingh, J. P. (Eds.): Review and revision of empirical critical loads and dose-response relationships, Coordination Centre for Effects, National Institute for Public Health and the Environment (RIVM), www.rivm.nl/cce, 2011.

Bobbink, R., Hornung, M., and Roelofs, J. G. M.: The effects of air-borne nitrogen pollutants on species diversity in natural and semi-natural European vegetation, J. Ecol., 86, 717-738, 1998.

Braithwaite, M. E., Ellis, R. W., and Preston, C. D.: Change in the British Flora 1987-2004, London, Botanical Society of the British Isles, 2006.

Clark, C. M. and Tilman, D.: Loss of plant species after chronic low-level nitrogen deposition to prairie grasslands, Nature, 451, 712-715, 2008.

Diekmann, M. and Falkengren-Grerup, U.: Prediction of species response to atmospheric nitrogen deposition by means of ecological measures and life history traits, J. Ecol., 90, 108-120, 2002.

Dupré, C., Stevens, C. J., Ranke, T., Bleeker, A., Peppler-Lisbach, C., Gowing, D. J. G., Dise, N. B., Dorland, E., Bobbink, R., and Diekmann, M.: Changes in species richness and composition in European acidic grasslands over the past 70 years: the contribution of cumulative atmospheric nitrogen deposition, Glob. Change Biol., 16, 344-357, 2010.

Ellenberg, H., Weber, H. E., Dull, R., Wirth, V., Werner, W., and Paulissen, D.: Zeigerwerte von pflanzen in Mitteleuropa, Scripta Geobotanica, 18, 1-248, 1991.

Fournier, N., Dore, A. J., Vieno, M., Weston, K. J., Dragosits, U., and Sutton, M. A.: Regional estimation of pollutant gas deposition in the UK: model description, sensitivity analysis and outputs, Atmos. Environ., 34, 3757-3777, 2000.

Grime, J. P.: Benefits of plant diversity to ecosytems: immediate, filter and founder effects, J. Ecol., 86, 902-910, 1998.

Hall, J., Bealey, B., and Wadsworth, R.: Assessing the Risks of Air pollution Impacts on the Condition of Areas/Sites of Special Scientific Interest, Peterborough, JNCC, 2006a.

Hall, J., Dore, A., Heywood, E., Broughton, R., Stedman, J., Smith, R., and O'Hanlon, S.: Assessment of the Environmental impacts Associated with the UK Air Quality Strategy, London, DEFRA, 2006b.

Hastie, T. J. and Tibshirani, R. J.: Generalised Additive Models, London, Chapman and Hall, 1990.

Hill, M. O. and Carey, P. D.: Prediction of yield in the Rothamsted Park Grass Experiment by Ellenberg indicator values, J. Veg. Sci., 8, 579-586, 1997.
Hill, M. O., Mountford, J. O., Roy, D. B., and Bunce, R. G. H.: Ellenberg's indicator values for British plants. ECOFACT Volume 2. Technical Annex., Institute of Terrestrial Ecology, 1999.

Hill, M. O., Preston, C. D., and Roy, D. B.: PLANTATT Attributes of British and Irish Plants: Status, Size, Life History, Geography and Habitats, Monkswood, Abbots Ripton, Huntingdon, UK, Centre for Ecology and Hydrology, 2004.

Hill, M. O., Preston, C. D., Bosanquet, S. D. S., and Roy, D. B.: BRYOATT: Attributes of British and Irish Mosses, Liverworts and Hornworts, Huntingdon, Centre for Ecology and Hydrology, 2007.

Isbell, F., Calcagno, V., Hector, A., Connolly, J., Harpole, W. S., Reich, P. B., Scherer-Lorenzen, M., Schmid, B., Tilman, D., Van Ruijven, J., Weigelt, A., Wilsey, B. J., Zavaleta, E. S., and Loreau, M.: High plant diversity is needed to maintain ecosystem services, Nature, 477, 199-202, 2011.

Jones, M. L. M., Wallace, H. L., Norris, D., Brittain, S. A., Haria, S., Jones, R. E., Rhind, P. M., Reynolds, B. R., and Emmett, B. A.: Changes in vegetation and soil characteristics in coastal sand dunes along a gradient of atmospheric nitrogen deposition, Plant Biol., 6, 598-605, 2004.

Laughlin, D. C.: Nitrification is linked to dominant leaf raits rather than functional diversity, J. Ecol., 99, 1091-1099, 2011.

Maskell, L. C., Smart, S. M., Bullock, J. M., Thompson, K., and Stevens, C. J.: Nitrogen Deposition causes widespread species loss in British Habitats, Glob. Change Biol., 16, 671-679, 2010.

Mountford, J. O., Lakhani, K. H., and Kirkham, F. W.: Experimental assessment of the effects of nitrogen addition under haycutting and aftermath grazing on the vegetation of meadows on a Somerset peat moor, J. Appl. Ecol., 30, 321-332, 1993.

NEGTAP: Transboundary air pollution: Acidification, eutrophication and ground-level ozone in the UK, Edinburgh, CEH, 2001.

Nilsson, J. and Grennfelt, P. E.: Critical Loads for sulphur and nitrogen: Copenhagen, Denmark, UNECE/Nordic Council of Ministers, 1988.

Preston, C. D., Pearman, D. A., and Dines, T. D.: New Atlas of the British Isles Flora, Oxford, Oxfornd University Press, 2002.

ROTAP: Review of Transboundary Air Pollution: Acidification, Eutrophication, Ground Level Ozone and Heavy Metals in the UK, Report to the Department for Environment, Food and Rural Affairs, Centre for Ecology and Hydrology, Edinburgh, 2011.

Smart, S. M., Ashmore, M. R., Scott, W. A., Hornung, M. H., Dragosits, U., Fowler, D., Sutton, M. A., Famulari, D., and Howard, D. C.: Detecting the large-scale signal of atmospheric $\mathrm{N}$ deposition across British ecosystems, Water Air and Soil Pollution Focus, 4, 269-278, 2004.

Smith, M. D. and Knapp, A. K.: Dominant species maintain ecosystem function with non-random species loss, Ecol. Lett., 6, 509517, 2003.

Smith, R. I., Fowler, D., Sutton, M. A., Flechard, C., and Coyle, M.: Regional estimation of pollutant gas dry deposition in the UK: model description, sensitivity analyses and outputs, Atmos. Environ., 34, 3757-3777, 2000.

Stevens, C. J., Dise, N. B., Mountford, J. O., and Gowing, D. J.: Impact of nitrogen deposition on the species richness of grasslands, Science, 303, 1876-1879, 2004.

Stevens, C. J., Thompson, K., Grime, J. P., Long, C. J., and Gowing, D. J. G.: Contribution of acidification and eutrophication to declines in species richness of calcifuge grasslands along a gradient 
of atmospheric nitrogen deposition, Funct. Ecol., 24, 478-484, 2010 .

Van den Berg, L. J. L., Vergeer, P., Rich, T. C. G., Smart, S. M., Guest, D., and Ashmore, M. R.: Direct and indirect effects of nitrogen deposition on species composition change in calcareous grasslands, Glob. Change Biol., 17, 1871-1883, 2011.
Wilson, E. J., Wells, T. C. E., and Sparks, T. H.: Are calcareous grasslands in the UK under threat from nitrogen deposition? - an experimental determination of a critical load, J. Ecol., 83, 823832, 1995. 